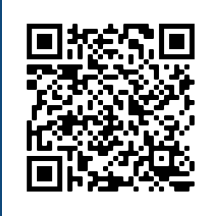

Keywords:

Annual diameter growth Distance-dependent tree growth model

Hegyi

Spearman's rank correlation coefficient

Received 18/12/2019 Accepted 10/04/2020

+Correspondence: gabriel.orso@ufpr.br
Gabriel Agostini Orsolat, Adriane Avelhaneda Mallmann ${ }^{\mathrm{lb}}$, Allan Libanio Pelissari $^{\text {lc }}$,Alexandre Behling ${ }^{\text {ld }}$, Afonso Figueiredo Filho ${ }^{2 a}$, Sebastião do Amaral Machado ${ }^{\text {le }}$

\section{HOW COMPETITION INDICES BEHAVE AT DIFFERENT NEIGHBORHOOD COVERAGES AND MODIFICATIONS IN A NATURAL ARAUCARIA FOREST IN SOUTHERN BRAZIL}

ORSO, G. A.; MALLMANN, A. A.; PELISSARI, A. L.; BEHLING, A.; FIGUEIREDO FILHO, A. MACHADO, S. A. How competition indices behave at different neighborhood coverages and modifications in a natural araucaria forest in southern Brazil. CERNE, v.26, n. 2, p.293300,2020

\section{HIGHLIGHTS}

The performance of competition indices varies with increasing plot sizes.

Modifications can improve the performance of competition indices.

Both distance-dependent and independent indices showed good results to assess competition.

The competition indices BAL and Hegyi were selected to predict annual diameter growth.

\section{ABSTRACT}

Tree-level growth models are being more used in heterogeneous forests, for they can take underlying processes, such as competition, into account. Although it is common in the forest literature to test several indices in order to define the most suitable for each study, the evaluation of plot sizes or competition radii is poorly addressed in competition studies. The objective of this work was to assess the effect of different plot sizes and competitor selection radii on distance-independent and distance-dependent competition indices, as well as test several modifications in previously created indices. We used data of diameter, canopy stratum and crown quality from two stem mapped measurements carried out in a six-year period. Both distance-dependent and independent indices were calculated for different plot sizes and competitor selection radii. The performance of plot sizes and neighborhood radii was evaluated via Spearman's rank correlation with the annual growth in diameter, and those with the largest correlation coefficient were included in a stepwise regression to estimate diameter growth. For almost all the indices the correlation increased as the plot size or radius increased. A $50 \mathrm{~m} \times 50 \mathrm{~m}$ square plot generated the strongest correlation for distance-independent indices. A 20 m radius resulted the largest correlation for the distancedependent indices. Modifications in some of the indices also improved their performance. The stepwise regression selected BAL and Hegyi indices to describe the diameter growth, which means that using only one competition index might not be enough to fully explain the overall competition.
' Federal University of Paraná, Curitiba, Paraná, Brazil - ORCID:0000-000 I-5002-0649a, 0000-0002-5588-9877b, 0000-0002-09 I 5-0238c, 0000-0002-7032-272 Id, 0000-0003-1010-4623e

2 Paraná Midwest State University, Curitiba, Paraná, Brazil - ORCID: 0000-000 I-9965-785 Ia 


\section{INTRODUCTION}

The tree-level approach is gaining ground in growth models, especially when more traditional tools developed for forest management are not able to represent some of the underlying processes of highly heterogenous forests (Gourlet-Fleury and Houllier, 2000; Phillips et al., 2003).

One of these processes is the competition among trees, which can be described as a negative interaction between two trees (Connell, 1990). Although there are several mechanisms that may result in competition, it is often treated as a contest for resources (Weiner, 1990; Schwinning and Weiner, 1998).

A possible way to account for competition in growth models is to include a competition index, which in theory summarizes the general environment of competition or the influence of local neighbors (Tomé and Burkhart, 1989), leading to a more accurate estimate of the growth capacity of a given tree.

Competition indices can be divided into distanceindependent and distance-dependent indices (Kuehne et al., 2019), and this division also names the distancedependent and independent growth model classes used in forest literature (Peng, 2000). The first type refers to those indices that do not require the location of any tree within the plot. These indices usually summarize the average competition inside the plot and are at first sight limited in their ability to provide information regarding a particular tree (Tomé and Burkhart, 1989; Peng, 2000). On the other hand, the distance-dependent competition indices require information that can only be calculated when the location of the trees within the plot is known, such as the distance between trees. With this information it is also possible to define a competition radius around the subject tree to include neighboring trees as competitors.

At some extent it is also possible to include concepts that might help to understand competition among trees, such as symmetric or asymmetric competition (Weiner, 1988; Connell, 1990). In symmetric competition, resources are shared proportionally to the size of the trees, and are often related to the availability of belowground resources like water or nutrients (Pretzsch and Biber, 20I0). In asymmetric competition larger trees have an advantage over smaller ones, and light is the main limiting resource (Weiner, 1990; Pretzsch and Biber, 2010). Inside the forest, however, these concepts are but the extremes of a continuum of possibilities (Weiner, 1990).

Competition indices can also be assigned to one of these types or modes of competition based on their composition or structure (Pommerening and Sánchez Meador, 2018; Kuehne et al., 2019).

Since many indices have a similar structure (Tomé and Burkhart, 1989), they are commonly classified into groups according to their main approach or assumptions to quantify competition, such as size ratio, area potentially available and zone of influence (Vanclay, 1994; Pommerening and Sánchez Meador, 2018). By grouping them, it is possible to properly understand them and eventually suggest or modify previously created indices.

This has led to a variety of studies over the years, exploring several indices which can be usually compared with each other to find the most suitable ones (Cunha and Finger, 20I3; Vatraz et al., 20I8). However, the effect of plot size or radius around the subject tree is rarely explored and evaluated. Since competition indices are based on a subject-neighbor relationship, different plot sizes might change the overall ability of an index to explain the competition of the subject tree (Alder and Synnott, 1992; Vatraz et al., 2018). In addition to plot size, minor modifications in the competition indices can lead to better performances than their unmodified counterparts (Tomé and Burkhart, 1989).

In Brazil, applied examples of this class of treelevel growth models in mixed natural forests range from the Amazon Rainforest (Cunha and Finger, 2013; Vatraz et al., 2018) to the Southern Brazil Seasonal Forest (Della-Flora et al., 2004).

This study aimed to evaluate the performance of distance-dependent and independent competition indices in different radii and plot sizes in an Araucaria Forest remnant located in southern Brazil. We also tested minor changes in some competition indices, aiming to find the most suitable indices to estimate the diameter growth.

Our hypothesis was that the competition indices might have different performances for different radii and plot sizes. We also theorized that modified indices can properly estimate diameter growth.

\section{MATERIALS AND METHODS}

\section{Study area}

The study area is a 15.24 ha forest located in Curitiba, Paraná state, Brazil, and is classified as a Mixed Ombrophilous Forest (Roderjan et al., 2002, Machado et al., 2008), commonly known as Araucaria Forest or Araucaria Moist Forest. The average monthly temperatures range from $20.5^{\circ} \mathrm{C}$ in January to $13{ }^{\circ} \mathrm{C}$ in July, and annual rainfall of $\mathrm{I}, 550 \mathrm{~mm}$ (Alvares et al., 
2013). The climate is Cfb according to the KöppenGeiger classification.

There are $\mathrm{I} 0 \mathrm{I}$ native tree species in the area, and Myrtaceae and Lauraceae are the most common families, accumulating $24.75 \%$ of the total (I5 Myrtaceae and 10 Lauraceae). The main species present include Paranápine (Araucaria angustifolia (Bertol.) Kuntze), cafezeiro (Casearia sylvestris Sw.), açoita-cavalo (Luehea divaricata Mart. \& Zucc), canela-sebo (Ocotea puberula (Rich.) Nees) and maria-mole (Symplocos tetrandra Mart.).

We used data from 12 stem mapped permanent sampling plots of $50 \mathrm{~m} \times 50 \mathrm{~m}$ established in 2007 and remeasured in 2013. These plots were part of a census project that covered the entire forest, and we selected the inner 12 in a way that they all shared at least one border, resulting in a continuous 3 ha sampling area. This was done so that we could simulate plot sizes larger than the plots themselves, as well as to remove border effects when calculating competition indices.

All trees with diameter at breast height $(\mathrm{dbh}) \geq 10$ $\mathrm{cm}$ were included (2,353 measured trees). The variables measured on the field were the circumference at $1.3 \mathrm{~m}$ of each tree, a qualitative height measure defined as canopy stratum (ST, I - Understory, 2 - Canopy, 3 - Emergent), and crown quality (CQ, I - Broken, 2 - Non-vigorous, 3 - Vigorous with reduced size, 4 - Vigorous with normal size). The individual basal area $g$ was calculated as in eq. (I) and the annual growth in diameter $(\Delta \mathrm{dbh})$ as in eq. (2), where gi is the individual basal area of the tree $\mathrm{i}$, in $\mathrm{m}^{2}$; dbht and $\mathrm{dbht}+\Delta \mathrm{t}$ are the diameters at breast height at the beginning and end of the period, respectively, in $\mathrm{cm} ; \Delta \mathrm{dbhi}$ is the annual diameter increment, in $\mathrm{cm}$.year ${ }^{-1}$; $\Delta \mathrm{t}$ is the period in years.

$g_{i}=\frac{d b h_{i}^{2} \cdot \pi}{40000}$

$\Delta d b h_{i}=\frac{d b h_{s+\Delta t}-d b h_{t}}{\Delta t}$

\section{Competition indices}

Both distance-independent (Table I) and distance-dependent (Table 2) competition indices used in this study were calculated in the statistical package $R$ (R Core Team, 2019).

The distance-independent indices tested were basal area in larger trees (BAL) in m2.plot-I and Glover \& Hool index $(\mathrm{GH})$, which can be classified as stand density indices (Pommerening and Sánchez Meador, 2018). We also included basal area (G) in $\mathrm{m} 2$.plot-I and the mean plot diameter $(\mathrm{dp})$ in $\mathrm{cm}$, which are occasionally used as competition indices and we found that they are suitable to demonstrate the effect of the subject-neighbor relationship.

The modified indices are denoted with a subscripted " $\mathrm{m}$ ", and for the distance-independent indices they consisted in removing the subject tree when calculating $\mathrm{Gm}$ and dpm. This was done based on the assumption that the relative weight of all trees increases as the plot size decreases, and that could overestimate the competition (e.g. a large tree in a small plot).

TABLE I Distance-independent competition indices evaluated in this study.

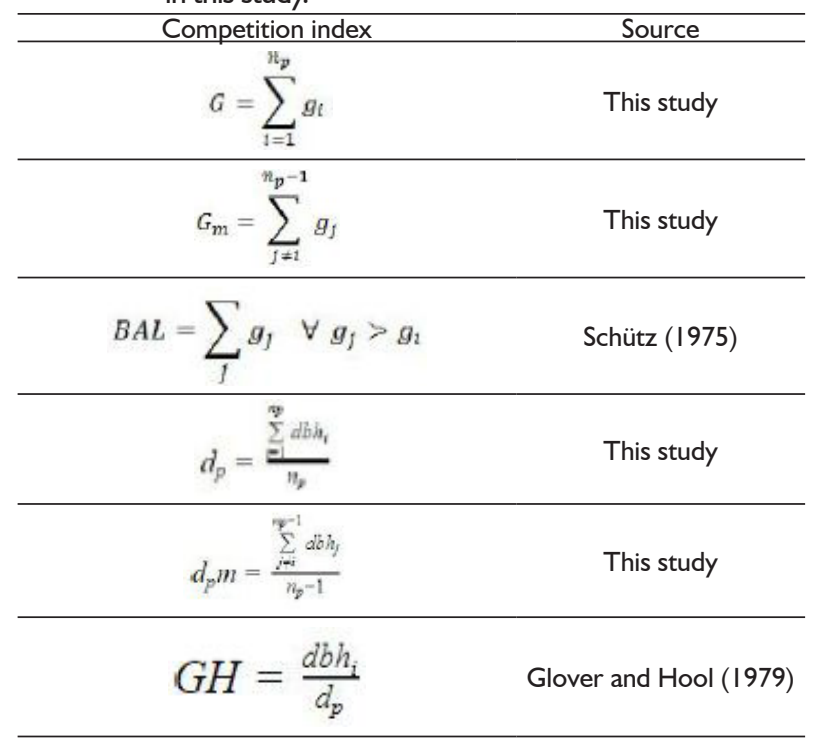

Where $i$ is the subject tree; $j$ is the competitor tree; $g$ is the individual basal area in $\mathrm{m} 2$; $\mathrm{dbh}$ is the diameter at breast height, in $\mathrm{cm}$; $\mathrm{np}$ is the number of trees within the plot.

The distance-dependent indices tested were Hegyi (H), Tome and Burkhart (TB), Martin and Ek (MEm) and Area Potentially Available (APAI e APA2), shown in Table 2. The first three are referred as size ratio or sizedistance types of competition indices, whereas the area potentially available is a group on its own (Vanclay, 1994).

The modifications (also denoted with a subscripted " $\mathrm{m}$ ") consisted in restricting the selection of neighboring trees in the $\mathrm{Hm}, \mathrm{TBm}$ and MEm indices, in a way that only neighbors in the same or upper strata of the subject tree were taken into account ( $\mathrm{ST} j \geq \mathrm{STi}$, where $\mathrm{j}$ is the neighbor tree and $i$ is the subject tree). The MEm index was directly calculated with the restriction.

This modification was based on the competition index in an attempt to select only the larger neighbors of a subject tree using the canopy stratum as a proxy for larger trees. The main reason for this was that size-ratio indices such as Hegyi commonly quantify two-sided competition (Kuehne et al., 2019), and the restriction would possibly account for an asymmetric share of resources (such as light, where the small trees cannot compete with taller ones, see Pommerening and Sánchez Meador (2018). 
TABLE 2 Distance-dependent competition indices evaluated in this study.

\begin{tabular}{cc}
\hline Competition index & Source \\
\hline$H=\sum_{j}\left(\frac{d b h_{i}}{d b h_{i}} \cdot L_{i j}^{-1}\right)$ & Hegyi \\
& $(1974)$ \\
\hline
\end{tabular}

$H_{m}=\sum_{j}\left(\frac{d b h_{i}}{d b h_{i}} \cdot L_{y}^{-1}\right) \quad \forall S T_{j} \geq S T_{i} \quad \begin{gathered}\text { Adapted from Hegyi } \\ \text { (1974) }\end{gathered}$

\begin{tabular}{|c|c|}
\hline$T B=\sum_{y}\left(\left(d b h_{j}-d b h_{i}\right) \cdot L_{i j}^{-1}\right)$ & $\begin{array}{l}\text { Tomé and Burkhart } \\
\qquad(1989)\end{array}$ \\
\hline$T B_{m}=\sum_{j}\left(\left(d b h_{j}-d b h_{t}\right) \cdot L_{v}^{-1}\right) \forall S T, \geq S T$, & $\begin{array}{c}\text { Adapted from Tomé } \\
\text { and Burkhart } \\
(1989)\end{array}$ \\
\hline 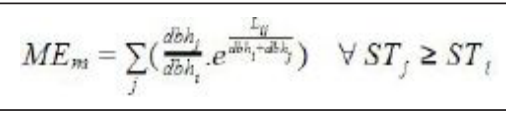 & $\begin{array}{c}\text { Adapted from Martin } \\
\text { and Ek } \\
(1984)\end{array}$ \\
\hline$A P A_{1}=\frac{A_{i}}{\overline{A_{j}}}$ & $\begin{array}{c}\text { Adapted from Daniels } \\
\text { et al. } \\
(1986) \\
\end{array}$ \\
\hline$A P A_{2}=\sum_{j} \frac{A_{i}}{A_{j}}$ & $\begin{array}{c}\text { Adapted from Daniels } \\
\text { et al. } \\
(1986)\end{array}$ \\
\hline
\end{tabular}

Where $i$ is the subject tree; $j$ is the competitor tree; $d b h$ is the diameter at breast height, in cm; Lij is the distance between trees i and j; ST is the canopy stratum; $A$ is the area of a Voronoi cell, in $\mathrm{m}^{2}$.

The area potentially available indices (APAI and APA2) were calculated according to Daniels et al. (1986), using a Voronoi diagram based on the location of the trees inside the plots (Figure I) with the spatstat package in $\mathrm{R}$ (Baddeley et al., 20I5), and the resulting cells were considered as the available area for each tree (Daniels et al., 1986). This diagram had each cell's area measured and we considered neighboring trees those whose cells shared a common edge with the cell of the subject tree (Daniels et al., 1986; Bérubé-Deschênes et al., 2017). For this reason, we were not able to try different neighborhood coverages for these competition indices.

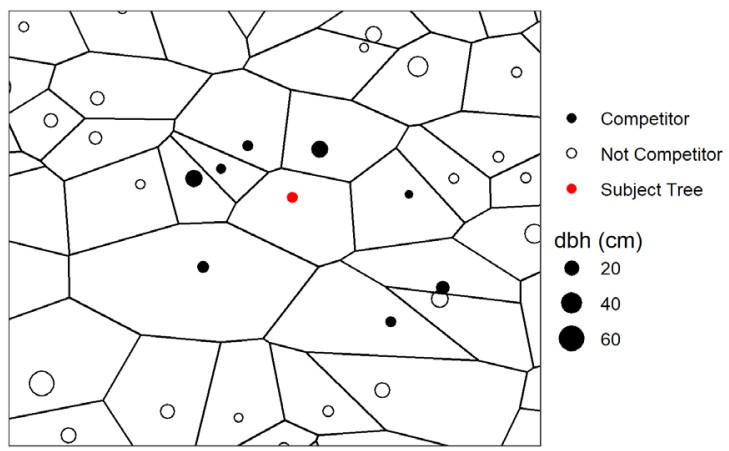

FIGURE I Example of the area potentially available indices (APA) based on voronoi diagram.

To test different plot sizes for the distanceindependent competition indices we divided the sampling area into minor square plots with sides of $10,15,20,25$, 50 and $100 \mathrm{~m}$ (areas ranging from $100 \mathrm{~m}^{2}$ to $10,000 \mathrm{~m}^{2}$ ). For the distance-dependent indices, competition radii with $3,5,7,10,12,15,17$ and $20 \mathrm{~m}$ were tested around the ORSO et al. subject tree (areas ranging from $28.28 \mathrm{~m} 2$ to I,256.64 $\mathrm{m}^{2}$ ), including all neighbors inside the radius.

There are still other methods to select the competing neighbors, such as a radius proportional to the size of the trees (Vanclay et al., 2013), crown overlap (Weber et al., 2018), or basal area factor (Silveira et al., 2015; McTague and Weiskittel, 2016). However, these procedures were not applied in this study, for they do not allow a straightforward control over plot sizes or neighborhood selection and therefore might hinder interpretations.

To define the best plot size or neighborhood selection radius, we used the Spearman's rank correlation $(\hat{\rho})$ between each competition index and the annual growth in diameter $(\Delta \mathrm{dbh})$ at a $95 \%$ confidence level. The correlation was calculated considering all 2,353 individuals in the sampling area.

The diameter growth ( $\Delta \mathrm{dbh})$ was estimated as a function of a linear model using a stepwise regression with a 10 -fold cross validation to select the explanatory variables, using the caret package (Kuhn, 2019) in R. Besides the competition indices, the other variables tested were diameter at the beginning of the period (dbht), crown quality (CQ), canopy stratum (ST) and the ecological group of the species (EG). For the competition indices with modified counterparts, only the version with the highest correlation was included in the model. Thus, the generic fitted growth model used was:

$\Delta \mathrm{dbh}=\mathrm{f}\left(\mathrm{dbh}_{\mathrm{f}}, \mathrm{CQ}, \mathrm{ST}, \mathrm{EG}\right.$, Competition Indices $)$

The criteria to select and keep variables in the model were the Akaike Information Criterion (AIC), root mean squared error (RMSE) and coefficient of determination $(r 2)$. Since many competition indices are built based on similar variables, the Variance Inflation Factor (VIF < I0) was used to control multicollinearity (Zhao et al., 20l3).

\section{RESULTS}

Table 3 summarizes the beginning and end of the period evaluated at the study area. The number of trees per hectare increased, which means that there are more trees being recruited than dying. In the meantime, both the basal area and mean diameter also increased.

Figure 2 displays the correlation value and its significance at $95 \%$ confidence level for all competition indices as the plot size or competition radius increases. Only $G$ and did not show evidence of significant correlation with diameter growth along most of the simulated plot sizes. 
TABLE 3 Summary statistics of diameter at breast height (dbh), number of trees $(\mathrm{n})$ and basal area $(\mathrm{g})$ of the study area.

\begin{tabular}{ccc}
\hline Attribute & Measurement I & Measurement 2 \\
\hline Mean diameter $(\mathrm{cm})$ & 17.35 & 18.88 \\
\hline Min $(\mathrm{cm})$ & 10.00 & 10.00 \\
\hline Max $(\mathrm{cm})$ & 81.30 & 84.03 \\
\hline Standard Deviation $(\mathrm{cm})$ & 9.93 & 10.53 \\
\hline First quartile $(\mathrm{cm})$ & 11.75 & 12.7 \\
\hline Median $(\mathrm{cm})$ & 14.07 & 15.6 \\
\hline Third quartile $(\mathrm{cm})$ & 18.62 & 20.63 \\
\hline $\mathrm{N}\left(\right.$ trees.ha $\left.^{-1}\right)$ & 645.21 & 691.34 \\
\hline $\mathrm{G}\left(\mathrm{m}^{2} . \mathrm{ha}^{-1}\right)$ & 21.59 & 25.17 \\
\hline
\end{tabular}

For the distance-independent indices (Figure 2A) the Spearman's rank correlation value tends to stabilize around a $50 \mathrm{~m}$ square plot side, which represents an area of $2500 \mathrm{~m}^{2}$. Although the modified competition indices remained with a very small correlation, omitting the subject tree improved both and, which led to statistically significant values of correlation for all plot sizes. BAL and HG had the largest values correlation coefficients with growth, with opposite signs (-0.32 and 0.33).

All distance-dependent competition indices showed a negative relationship with growth (Figure $2 \mathrm{~B}$ ), and with exception of , all reached the maximum value of coefficient of correlation at $20 \mathrm{~m}(1,256.64 \mathrm{~m} 2)$, the largest radius evaluated. The modified competition indices and followed the same trend as their unmodified counterparts, although showed a stronger relationship with growth than .

Based on the maximum values of correlation, we chose an average plot size of $50 \mathrm{~m} \times 50 \mathrm{~m}$ for the distance-independent competition indices, and $20 \mathrm{~m}$ as competition radius around each tree. The competition indices calculated with these values were added to the stepwise regression.

The competition indices and were both not statistically significant ( $=0.013$ for and $=0.026$ for ). Variables ST, CQ, EG and were all statistically significant ( $=0.413,0.289,0.123$ and 0.333 , respectively).

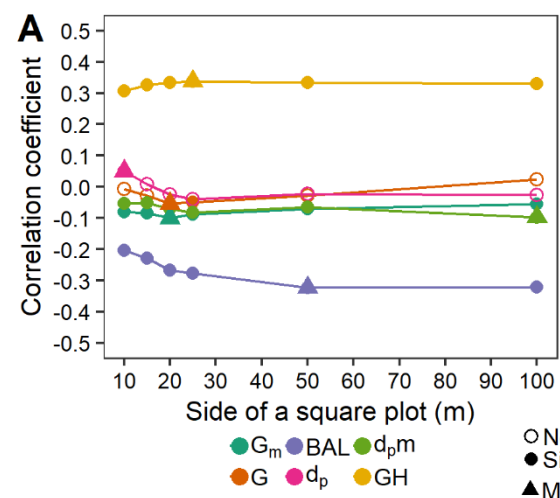

FIGURE 2 Changes in the correlation value between competition indices and annual growth for (a) distance-independent and (b) distance dependent competition indices, considering a $95 \%$ confidence level.
TABLE 4 Selected variables, parameter estimates and fit statistics of the growth model after the stepwise procedure.

\begin{tabular}{cccc}
\hline Variable & $\begin{array}{c}\text { Parameter } \\
\text { Estimate }\end{array}$ & p-value & VIF \\
\hline Intercept & 0.0585 & 0.2638 & \\
\hline $\mathrm{dbht}$ & 0.0018 & 0.0420 & 3.52 \\
\hline $\mathrm{CC}$ & 0.0566 & 0.0000 & 1.16 \\
\hline $\mathrm{ST}$ & 0.0722 & 0.0000 & 1.93 \\
\hline $\mathrm{BAL}$ & -0.0180 & 0.0069 & 4.58 \\
\hline $\mathrm{Hm}$ & -0.0050 & 0.0000 & 3.02 \\
\hline $\mathrm{r}^{2}$ & 0.2262 & & \\
\hline RMSE $\left(\mathrm{cm}_{\text {year }}{ }^{-1}\right)$ & 0.2216 & & \\
\hline
\end{tabular}

The variables selected by the stepwise procedure can be seen in Table 4, and the final model is displayed in eq. (4), where are the parameter estimates shown in Table 4. The intercept was not statistically significant, and the model could only poorly explain the growth variance $(r 2=0.2262)$. The variance inflation factor indicated that there is no considerable multicollinearity (VIF < 5) effect among the selected variables (Zhao et al., 20l3).

$\Delta d b h=\beta_{0}+\beta_{1} \cdot d b h_{t}+\beta_{2} \cdot C C+\beta_{3} \cdot S T+\beta_{4} \cdot B A L+\beta_{5} \cdot H_{m}$

\section{DISCUSSION}

The sign of the correlation is closely related to the composition of the competition index. The BAL index, for example, increases as the number of trees with larger individual basal area than the subject tree increases (Martins et al., 20I I), i.e., larger values of the index correspond to smaller trees, which results in a negative correlation. On the other hand, the Glover \& Hool index $(\mathrm{GH})$ has a positive correlation with diameter growth, since larger trees will result in a larger value for this index (Vatraz et al., 2018). Most distance-dependent competition indices have a negative relationship with growth, as they usually are a sum of the interference of local neighbors (Tomé and Burkhart, 1989).

The mean plot diameter (dp) is not suitable as a competition index. In addition to a very small relationship with diameter growth, this variable changed its sign as

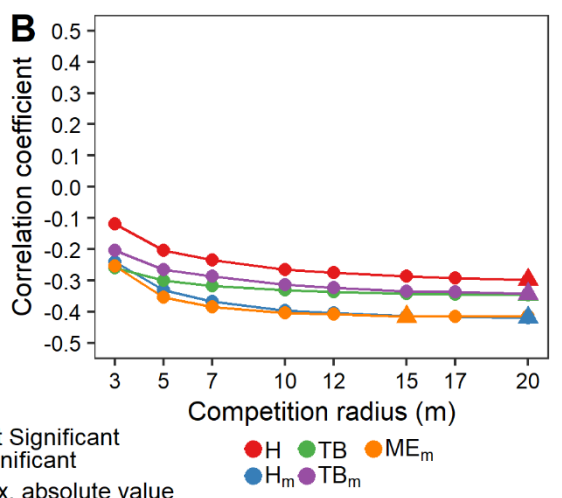


the plot size increased. We hypothesize that this volatile behavior is caused due to the relative weight of the subject tree inside the plot. In small plots the subject tree might have a great influence in the mean plot diameter.

The modified index supports this theory. It showed a statistically significant and negative relationship with diameter growth (green line in Figure 2A), since an increase in means that there are larger trees inside the plot, thus increasing competition for resources. The same effect occurred with and, for the modified index showed better results than de unmodified version.

The correlation values are still extremely low for these variables, but at the same time they are very sensitive to any modification and provide good indicators of the effects of the subject tree when calculating competition.

The BAL index increased its correlation with diameter growth as plot size increased and stabilized with a $2500 \mathrm{~m} 2$ square plot. The same plot size was considered optimal by Vatraz et al. (2018) in the Amazon forest. However, this plot size may not be ideal in some cases, and literature also reports different plot sizes that maximizes the performance of the BAL index (Burton, 1993). The GH index, on the other hand, does not appear to be affected by plot size, and might be used when plot size is a limiting factor.

Regarding the distance-dependent indices, $\mathrm{H}, \mathrm{Hm}$, $\mathrm{TB}, \mathrm{TBm}$, and were statistically significant and showed a tendency of increasing correlation with diameter growth as the radius increased. The highest correlations were achieved with a $20 \mathrm{~m}$ radius, and would possibly increase for larger radii, though in some forest inventories the plot size might limit this competition radius. Based on Figure 2, smaller radii such as $15 \mathrm{~m}$ or $12 \mathrm{~m}$ could also be used. Castro et al. (2014) defined values between 3 and $6 \mathrm{~m}$ to select competitors in a Seasonal Forest remnant located in Minas Gerais state.

The $\mathrm{H}$ and $T B$ indices express the sum of the size relationships between the subject tree and the neighboring trees. The Tomé and Burkhart's (1989) index had a better result compared to the Hegyi index. The use of subtraction as a measure of scale between the subject tree and its neighbors allows the occurrence of negative results, which may allow the measurement of other interactions between plants besides competition (Pommerening and Sánchez Meador, 2018).

The modification tested for distance-dependent indices showed separate responses for $\mathrm{Hm}$ and $\mathrm{TBm}$. For the Hegyi index, the restriction $\left(S T_{j} \geq S T_{i}\right)$ improved the correlation, but for TB there was no major contribution to the index performance.
This might be caused by the ratio relationship between subject and neighbor trees of the Hegyi index, for both smaller and larger trees increase the competition index, whereas the difference between dimensions of trees used in the TB index takes the sign into account (Tomé and Burkhart, 1989). The same authors have also pointed out a necessity to somehow separate smaller from larger trees in Hegyi's (1974) index.

These results corroborate the hypothesis that an asymmetric share of resources is more correlated with diameter growth, therefore light might be the limiting factor for growth in the study area (Pretzsch and Biber, 20I0).

The Martin \& Ek index (MEm) also showed a close relationship to diameter growth. This index has also been recently used by Kahriman et al. (2018) and was selected as a major contributor to explain diameter growth.

The other variables evaluated, the largest correlation value with diameter growth was the canopy stratum (ST). Potentially available area indices (APAI and APA2) do not appear to have any relationship with diameter growth. Knowing that crown size is an attribute closely related to tree growth (Cunha et al., 2013), it is possible that the areas of the Voronoi cells do not properly represent the crown shape or the area occupied by the trees. Our main hypothesis is that the arrangement created by the Voronoi diagram will only reflect the available area when all trees start occupying the area at the same time, such as in a planted forest stand. Daniels et al. (1986) evaluated competition indices for Pinus taeda L. stands and concluded that the area potentially available was a good index for growth prediction models when other tree and stand attributes are already known, corroborating the rationale discussed here.

The final model to predict diameter growth (eq. (4)) included one distance-independent and one distance-dependent competition index, respectively BAL and. Both BAL and Hegyi competition indices are widely adopted in forest literature (Silveira et al., 2015; Orellana et al., 2016; Weiskittel et al., 2016; Hess et al., 2018; Kahriman et al., 2018). The inclusion of both competition indices suggests that a single competition index might not be enough to fully explain the competition (Kuehne, et al., 2019), and that different types of competition indices are suitable for different components of the overall competition (Tomé and Burkhart, 1989).

\section{CONCLUSION}

Both distance-independent and distancedependent competition indices can change the relationship with diameter growth at different plot sizes or competition radii. The Basal Area in Larger Trees (BAL) was the best distance-independent competition 
index, and a modified Hegyi index $(\mathrm{Hm})$ was selected as the best distance-dependent competition index. The best plot size for distance-independent indices was a 50 $\mathrm{m} \times 50 \mathrm{~m}$ square plot, while the best competition radius was $20 \mathrm{~m}$ for distance-dependent indices.

Changes in the competition indices proved beneficial to improve the performance of the competition indices. In small plots, the effect of the subject tree should not be neglected, as well as the mode of competition or main limiting factor in the area.

\section{AKNOWLEDGEMENTS}

We would like to thank the National Council for Scientific and Technological Development (CNPq) for providing the scholarship to the first two authors.

\section{REFERENCES}

ALDER, D.; SYNNOTT, T. J. Permanent sample plot techniques for mixed tropical forest. Oxford Forestry Institute: Oxford, 124 p., 1992.

ALVARES, C. A.; STAPE, J. L.; SENTELHAS, P. C.; GONÇALVES, J. L. M; SPAROVEK, G. Köppen's climate classification map for Brazil. Meteorologische Zeitschrift, v. 22, n. 6, p. 7II- 728, 20 I3.

BADDELEY, A.; RUBAK, E.; TURNER, R. Spatial Point Patterns: Methodology and Applications with $\mathbf{R}$. Chapman and Hall: London, 2015.

BÉRUBÉ-DESCHÊNES, A.; FRANCESCHINI, T.; SCHNEIDER, R. Quantifying competition in white spruce (Picea glauca) plantations. Annals of Forest Science, v. 74, 2017.

BURTON, P. J. Some limitations inherent to static indices of plant competition. Canadian Journal of Forest Research, v. 23, p. $2|4|-2152,1993$.

CASTRO, R.; SOARES, C.; LEITE, H.; SOUZA, A.; MARTINS, F.; NOGUEIRA, G.; OLIVEIRA, M.; SILVA, F. Competição em Nível de Arvore Individual em uma Floresta Estacional Semidecidual. Silva Lusitana, v. 22, n. I, p. 43-66, 2014.

CONNELL, J. H. Apparent versus "real" competition in plants. In: GRACE, J. B.; TILMAN, D. Perspectives on Plant Competition. Academic Press: San Diego, p. 9-26, 1990.

CUNHA, T. A.; FINGER, C. A. G. Competição assimétrica e o incremento diamétrico de árvores individuais de Cedrela odorata L. na Amazônia ocidental. Acta Amazonica, v. 43, n. I, p. 9-I8, 2013.

CUNHA, T. A.; FINGER, C. A. G.; SCHNEIDER, P. R. Linear mixed model to describe the basal area increment for individual Cedro (Cedrela odorata L.) trees in occidental Amazon, Brazil. Ciência Florestal, v. 23, n. 3, p. 46I-470, 2013.

DANIELS, R. F.; BURKHART, H. E.; CLASON, T. R. A comparison of competition measures for predicting growth of loblolly pine trees. Canadian Journal of Forest Research, v. 16, p. 1230-1237, 1986.
DELLA-FLORA, J. B.; DURLO, M. A.; SPATHELF, P. Modelo de incremento para árvores singulares - Nectandra megapotamica (Spreng.) Mez. Ciência Florestal, v. I4, n. I, p. I65-177, 2004.

GOURLET-FLEURY, S.; HOULLIER, F. Modelling diameter increment in a lowland evergreen rain forest in French Guiana. Forest Ecology and Management, v. I3 I, p. 269-289, 2000

GLOVER, G. R.; HOOL, J. N. A basal area ratio predictor of loblolly pine plantation mortality. Forest Science, v. 25, p. 275-282, 1979.

HEGYI, F. A simulation model for managing jack-pine stands. In: Fries, G. (Ed.) Growth models for tree and stand simulation. Royal College of Forestry, Stockholm, Res. Note 30, p. 74-90, 1974.

HESS, A. F.; RICKEN, P.; CIARNOSCHI, L. D. Dendrocronologia, incremento e manejo florestal em floresta de araucária SC. Ciência Florestal, v. 28, n. 4, p. I568-I582, 2018.

KAHRIMAN, A.; SAHIN, A.; SÖNMEZ, T.; YAVUZ, M. A novel approach to selecting a competition index: the effect of competition on individual-tree diameter growth of Calabrian pine. Canadian Journal of Forest Research, v. 48, p. I-10, 2018.

KUEHNE, C.; WEISKITTEL, A. R.; WASKIEWICZ, J. Comparing performance of contrasting distanceindependent and distance-dependent competition metrics in predicting individual tree diameter increment and survival within structurally heterogeneous, mixed-species forests of Northeastern United States. Forest Ecology and Management, v. 433, p. 205-216, 2019.

KUHN, M. Caret: Classification and Regression Training. Reference manual, 2019. Available at https://cran.r-project. org/web/packages/caret/caret.pdf

MACHADO, S. A.; NASCIMENTO, R. G. M.; AUGUSTYNCZIK, A. L. D.; SILVA, L. C. R.; FIGURA, M. A.; PEREIRA, E. M.; TÉO, S. J. Comportamento da relação hipsométrica de Araucaria angustifolia no capão da engenharia florestal da UFPR. Pesquisa Florestal Brasileira, p. 5-16, 2008.

MCTAGUE, J. P.; WEISKITTEL, A. R. Individual-tree competition indices and improved compatibility with standlevel estimates of stem density and long-term production. Forests, v. 7, n. 10, 2016.

MARTIN, G. L.; EK, A. R. A comparison of competition measures and growth models for predicting plantation red pine diameter and height growth. Forest Science, v. 30, n. 3, p. $731-743,1984$

MARTINS, F. B.; SOARES, C. P. B.; LEITE, H. G.; SOUZA, A. L.; CASTRO, R. V. O. Índices de competição em árvores individuais de eucalipto. Pesq. Agropec. Bras., v. 46, n. 9 , p. 1089-1098, 20 I I. 
ORELLANA, E.; FIGUEIREDO FILHO, A.; PÉLLICO NETTO, S.; VANCLAY, J. K. Predicting the dynamics of a native Araucaria forest using a distance-independent individual tree-growth model. Forest Ecosystems, v. 3, p. I-II, 2016.

ORELLANA, E.; FIGUEIREDO FILHO, A.; PÉLLICO NETTO, S.; VANCLAY, J. K. A distance-independent individual-tree growth model to simulate management regimes in native Araucaria forests. Journal of Forest Research, v. 22, n. I, p. 30-35, 2017.

PENG, C. Growth and yield models for uneven-aged stands: past, present and future. Forest Ecology and Management, v. I32, p. 259-279, 2000.

PHILLIPS, P. D.; BRASH, T. E.; YASMAN, I.; SUBAGYO, P.; van GARDINGEN, P. R. An individual-based spatially explicit tree growth model for forests in East Kalimantan (Indonesian Borneo). Ecological Modelling, v. I59, p. I-26, 2003.

POMMERENING, A.; SÁNCHEZ MEADOR, A. J. S. Tamm review: Tree interactions between myth and reality. Forest Ecology and Management, v. 424, p. 164-I76, 2018.

PRETZSCH, H. ; BIBER, P. Size-symmetric versus sizeasymmetric competition and growth partitioning among trees in forest stands along an ecological gradient in central Europe. R CORE TEAM. $R$ : A language and environment for statistical computing. $R$ Foundation for Statistical Computing : Vienna, 2019.

RODERJAN, C. V.; GALVÃO, F.; KUNIYOSHI, Y. S.; HATSCHBACH, G. G. As unidades fitogeográgicas do estado do Paraná. In : Fitogeografia do Sul da América, Editora UFSM : Santa Maria, n. 24, 152 p ., 2002.

SCHÜTZ, J.-P. Dynamique et conditions d'équilibre de peuplements jardinés sur les stations de la hêtraie à sapin. Birmensdorf, v. 126, n. 9, p. 637-67I, 1975.

SCHWINNING, S. ; WEINER, J. Mechanisms determining the degree of size asymmetry in competition among plants. Oecologia, v. II3, p. 447-455, 1998.
SILVEIRA, B. D. da; FLORIANO, E. P.; NAKAJIMA, N. Y.; HOSOKAWA, R. T.; ROSOT, N. C.; GRACIOLI, C. R. Relação da morfometria e competição com o crescimento de Trichilia claussenii em um fragmento de Floresta Semidecidual, RS. Floresta, v. 45, n. 2, p. 373-382, 2015.

TOMÉ, M.; BURKHART, H. E. Distance-dependent competition measures for predicting growth of individual trees. Forest Science, v. 35, n. 3, p. 816-831, 1989.

VANCLAY, J. K. Modelling forest growth and yield: applications to mixed tropical forests. $C A B$ International, 1994. 313p.

VANCLAY, J. K.; LAMB, D.; ERSKINE, P. D.; CAMERON, D. M. Spatially explicit competition in a mixed planting of Araucaria cunninghamii and Flindersia brayleyana. Annals of Forest Science, v. 70, p. 6II-619, 2013.

VATRAZ, S.; SILVA, J. N. M.; ALDER, D. Competição versus incremento de árvores em floresta ombrófila densa no estado do Amapá - Brasil. Ciência Florestal, v. 28, n. 3, p. III8-II27, 2018.

WEBER, V. P.; FINGER, C. A. G.; COSTA, E. A.; ZIMMERMANN, A. P. L.; LONGHI, R. V. Modelagem linear generalizada para descrever $\circ$ incremento em área transversal de árvores individuais de imbuia. Floresta, v. 48, n. I, p. I23-132, 2018.

WEINER, J. Variation in the performance of individuals in plant populations. In: DAVY, A. J.; HUTCHINGS, M. J.; WATKINSON, A. R. (Ed.). Plant Population Ecology. Oxford: Blackwell Scientific Publications, p. 59-8I, 1988.

WEINER, J. Asymmetric competition in plant populations. Trends in Ecology and Evolution, v. 5, n. I I, p. 360-364, 1990.

WEISKITTEL, A.; KUEHNE, C.; MCTAGUE, J. P.; OPPENHEIMER, M. Development and evaluation of an individual tree growth and yield model for the mixed species forest of the Adirondacks Region of New York, USA. Forest Ecosystems, v. 3, n. I, p. I-I7, 2016.

ZHAO, L.; LI, C.; TANG, S. Individual-tree diameter growth model for fir plantations based on multi-level linear mixed effects models across southeast China. Journal of Forest Research, v. 18, n. 4, p. 305-315, 2013. 